\title{
Development of Fly Ash Containing Catalytic Vitreous Enamel Coatings
}

\author{
Buğra Çiçek ${ }^{*}$, \\ ${ }^{1}$ Yıldız Technical University, Department of Metallurgical and Materials Science Engineering, Esenler, Istanbul (ORCID: 0000-0001-8195-4153)
}

(First received 16 August 2019 and in final form 26 August 2019)

(DOI: $10.31590 /$ ejosat.603490)

\begin{abstract}
ATIF/REFERENCE: Çiçek, B. (2019). Development of Fly Ash Containing Catalytic Vitreous Enamel Coatings. European Journal
\end{abstract} of Science and Technology, (16), 948-959.

\begin{abstract}
Fly ashes are the by products from coal based raw materials of thermal power plants that are gathered with electro filters or cyclones. Due to the utilization possibility of fly ash particles varying applications Fly Ash is considered as a byproduct of thermal power plants. Investigation on possible use of fly ash in enamel production are reported. New enamel frits compositions were developed in order to utilize the fly ash in most efficient in their glass - ceramic matrix. Catalytic enamel frits were selected to be studied due to their high metallic oxide amounts compared to other enamel frits. Fly ash particles are added to the developed catalytic enamel frit in 1 wt.\%, 5 wt. $\%$ and $10 \mathrm{wt} . \%$ in order to investigate the possible alternative usage of fly ash by products. Catalytic activity of the prepared enamels tested with ISO 8291 Test Standard and also, the surface roughness and gloss values are determined. Gloss values were increased compared to the standart enamel compositions in a tolerable amount. $1 \mathrm{wt} . \%, 5 \mathrm{wt} . \%$ and $10 \mathrm{wt} . \%$ fly ash addition, the gloss values was increased up tp 3.3, 10 and 36.6\%, respectively. Surface roughness of the standard enamel coating was $96 \mu \mathrm{m}$ and with 1 wt.\%, 5 wt. \% and $10 \mathrm{wt} . \%$ fly ash addition the roughness values increase 14.5, 28.1 and $33.3 \%$. The results showed that addition of fly ash into the catalytic enamel frit did not change the ISO 8291 Test results which are 8 cycles for all the samples. Fly ash particles did not distort the catalytic enamel layer and did not impair the catalytic properties.
\end{abstract}

Keywords: Fly ash, Enamel, Frit, Sustainability, Recycling

\section{Introduction}

Thermal power plants produce three types of ashes: bottom ash which is heavy since the bottom ash is a coarser component of coal ash so that cannot transport by flue gases and comprising about $10 \%$ of the waste, raw ash which is obtained in the cyclone type furnaces and fly ash (Türker, Erdoğan, Katnaş, \& Yeğinobalı, 2009) (Ramzi Hannan, Shahidan, Maarof, \& Noorwirdawati, 2017). Since the fly ash is an insalubrious substance to the environment and human body when it's released (Sahu \& Jayaram, 2000), its interaction with the air is blocked by cyclone or electro filters and it is collected in cyclone or electro filters by transporting flue gases from the combustion of pulverized coal in thermal power plants. Figure 1 shows the ash production in thermal power plants.

The molten material resulting from the combustion of coal at high temperatures, cools down and becomes partially or completely spherical shaped ash particles. These glass-like ash particles are very fine $(0.5-150 \mu \mathrm{m})$ and are called fly ash because of their entrainment with flue gases (Sear, 2001).

\footnotetext{
${ }^{1}$ Corresponding Author: Y1ldız Technical University, Department of Metallurgical and Materials Science Engineering, Esenler, Istanbul, ORCID: 0000-0001-8195-4153, bugracicek@gmail.com
} 


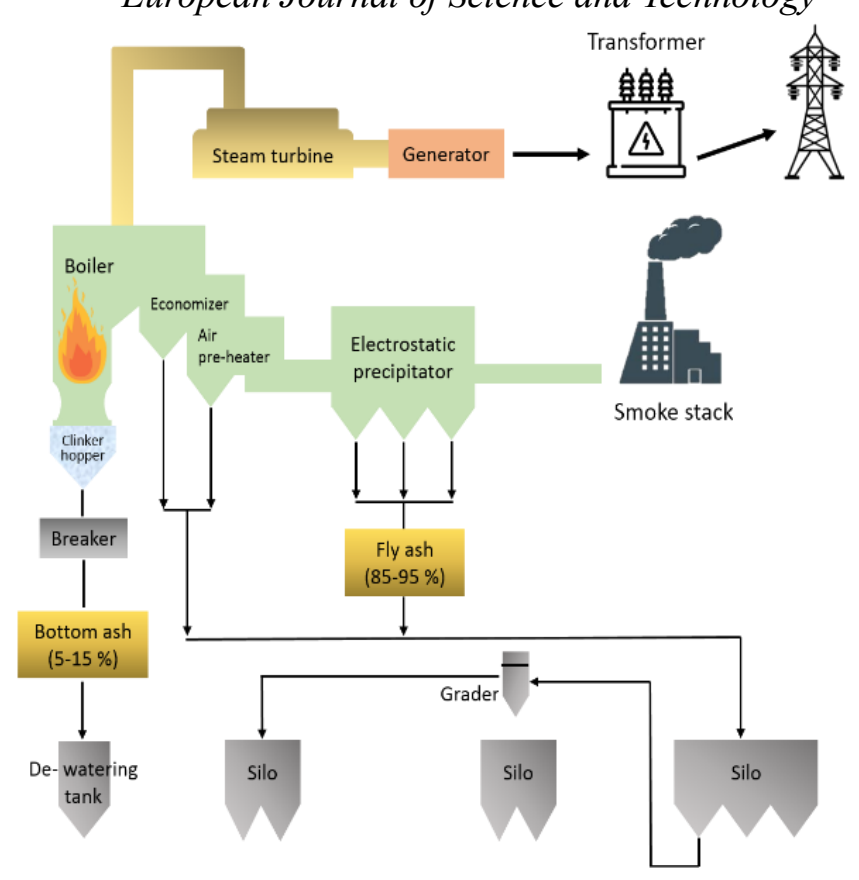

Figure 1 Simulation of ash generation from a power plant (Clean Coal Technologies in Japan, 2007)

The main compounds in the fly ash depend on the type of the fly ash but most of the fly ash compounds consist of $\mathrm{SiO}_{2}, \mathrm{Al}_{2} \mathrm{O}_{3}$, $\mathrm{Fe}_{2} \mathrm{O}_{3}$ and $\mathrm{CaO}$ with minority of $\mathrm{MgO}, \mathrm{SO}_{3}$ and alkaline oxides such as $\mathrm{Na}_{2} \mathrm{O}$ and $\mathrm{K}_{2} \mathrm{O}$. The percentage of the main compounds states the class of the fly ash (Türker, Erdoğan, Katnaş, \& Yeğinobal1 , 2009). Fly ashes classified as their chemical compounds with respect to ASTM C 618 Standard. The standard classifies the fly ashes as F (with low $\mathrm{CaO}$ and pozzolanic characteristic) and C classes (with higher $\mathrm{CaO}$ and pozzolanic and binder characteristic) (ASTM, 2005).

The term glass-ceramics refers to an inorganic material that blends two types of materials to form a product that is in a class of its own between glasses and polycrystalline ceramics (Höland \& H.Beall, Glass-Ceramics, 2013). They are multi-crystalline materials which contains crystalline and glass phases together, that produced by controlled crystallization of glass with special compositions, which can have high flexural strength (up to $500 \mathrm{MPa}$ ), optimal toughness (3 MPa $\sqrt{\mathrm{m}}$ ), high Vickers hardness (700 MPa), high refractoriness and low thermal expansion coefficient dependent on the composition of glass-ceramic (Höland \& Beall, Glass-Ceramic Technology, 2002) .

The production of glass, ceramic and glass-ceramic structures with the fly ash addition is a widely studied subject in the materials science other recycling related affairs (Karamanova \& Karamanov, 2009), (Erol M. Et al 2004). Production of glass-ceramic structures from fly ashes has widely studied in recent years (Kim, Kim, Oshikawa, \& Ikeda, 2003) (Cheng, Ueng, Chen, \& Chiu, 2002) (Barberio, et al., 2010). The researches state that the composition of fly ash, the fuel of the thermal power plants since the composition of fly ash is affected by the different fuel types, have high effect for glass-ceramic properties.

Glass-ceramic coatings with catalytic crystalline phase is a well-known technology. The catalytic coating in the enamel technology allows disposing food deposits at household oven firing temperatures (about $250{ }^{\circ} \mathrm{C}$ ) owing to the catalytic particles in the vitreous enamel and the porous structure of the enamel coating (Bragina, et al., 2015). As oxidation catalysts, the transition metals and their oxides, borides and silicides are commonly used. As decomposition catalysts, acid and activated clays, synthetic and/or natural zeolites, aluminates and magnesium-aluminum silicates are used (Shalygina, Bragina, \& Kuryakin, 2012).

The catalytic reactions are occurred as below:

$\mathrm{R}-\mathrm{COOH} \leftrightarrow \mathrm{R}-\mathrm{COO}^{-}+\mathrm{H}^{+}$

(Me)O. $\mathrm{Al}_{2} \mathrm{O}_{3} \cdot \mathrm{nSiO}_{2} \cdot \mathrm{mH}_{2} \mathrm{O}+\mathrm{H}^{+} \rightarrow(\mathrm{H}) \mathrm{O} . \mathrm{Al}_{2} \mathrm{O}_{3} \cdot \mathrm{nSiO}_{2} \cdot \mathrm{mH}_{2} \mathrm{O}+\mathrm{Me}^{+}$

$\mathrm{R}-\mathrm{COO}^{-}+\mathrm{Me}^{+} \rightarrow \mathrm{R}-\mathrm{COOMe}$

$2(\mathrm{R}-\mathrm{COOMe}) \rightarrow \mathrm{R}-\mathrm{CO}-\mathrm{R}+\mathrm{MeCO}_{3}$

$\mathrm{MeCO}_{3} \rightarrow \mathrm{MeO}+\mathrm{CO}_{2}$

$\mathrm{MeO}+\mathrm{H}_{2} \mathrm{O} \rightarrow \mathrm{MeOH}+\mathrm{H}_{2}$

(H)O. $\mathrm{Al}_{2} \mathrm{O}_{3} \cdot \mathrm{nSiO}_{2} \cdot \mathrm{mH}_{2} \mathrm{O}+\mathrm{MeOH} \rightarrow(\mathrm{Me}) \mathrm{O} \cdot \mathrm{Al}_{2} \mathrm{O}_{3} \cdot \mathrm{nSiO}_{2} \cdot \mathrm{mH}_{2} \mathrm{O}+\mathrm{H}_{2} \mathrm{O}$ 
Me : Monovalent metal atom

The $\mathrm{H}^{+}$ions that released from the ionization of carbonic acid $\mathrm{R}-\mathrm{COOH}$ (1), runs the ion Exchange of Me (2). The product of (1), $\mathrm{R}-\mathrm{COO}^{-}$anion, reacts with $\mathrm{Me}^{+}$and forms $\mathrm{R}-\mathrm{COOMe}$ salt. The decarboxylation reaction in (4) forms a ketone $(\mathrm{R}-\mathrm{CO}-\mathrm{R})$ and a metal carbonate. The carbonate decomposes to $\mathrm{CO}_{2}$ gas and metal oxide as shown in (5). This metal oxide is greatly hydroscopic and turns into hydroxide of metal with release of $\mathrm{H}_{2}$ gas as shown in (6). The aqueous alumina-silicate structure in (2), gives a reaction with metal hydroxide as shown in (7). The ketone in the (4) is reduced to secondary alcohol by hydrogen that has released in (6) as represented by (8). This alcohol reacts with oxygen in the air by the catalytic action of catalyst metal oxides and decomposes to carbon dioxide and water (United States Patent No. US4180482A, 1979).

Figure 2 Optical microscopy image of the studied fly ash sample.

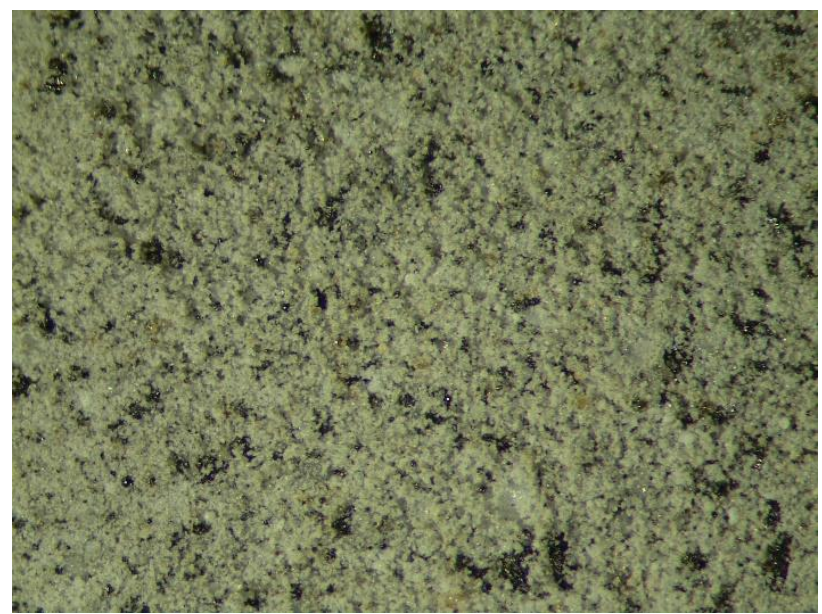

In this study, the fly ash composition is evaluated and a frit composition that shows the most similarity with fly ash has found. The high iron and aluminum oxide contents were the limitation compounds. It is aimed to investigate the workableness and structural effects of fly ash addition into the frit composition with different percentages.

\section{Materials and Methods}

The fly ash particles derived from Aksa Energy, Thermal Power Plant (Yalova, Turkey). The particle size of the fly ash particles obtained as $44.5 \mu \mathrm{m}$ via MasterSizer 2000 device. The chemical composition of the fly ash is evaluated by X-ray fluorescence (XRF) analysis and the results are shown in Table 1. Also, optical microscopy image is obtained via Olympos SZ 61 optical microscope and it's shown in Fig. 2.

Table 1. Chemical composition of the studied fly ash

\begin{tabular}{|l|l|}
\hline Formula & Concentration (\%) \\
\hline $\mathrm{SiO}_{2}$ & $61-63$ \\
\hline $\mathrm{Al}_{2} \mathrm{O}_{3}$ & $24-26$ \\
\hline $\mathrm{Fe}_{2} \mathrm{O}_{3}$ & $3-6$ \\
\hline $\mathrm{CaO}$ & $3-4$ \\
\hline $\mathrm{K}_{2} \mathrm{O}$ & $1.5-2$ \\
\hline $\mathrm{MgO}$ & $0.5-1.5$ \\
\hline $\mathrm{SO}_{3}$ & $0.5-0.7$ \\
\hline Other oxides & $2.5-2.8$ \\
\hline
\end{tabular}

According to XRF analysis the fly ash is rich with $\mathrm{SiO}_{2}$ and the other oxides in the structure are $\mathrm{Al}_{2} \mathrm{O}_{3}, \mathrm{Fe}_{2} \mathrm{O}_{3}$ and $\mathrm{CaO}$ from the most to less. Hence, the studies focused on the frits that show the most similarity of chemical composition with the fly ash since the relatively high $\mathrm{Al}_{2} \mathrm{O}_{3}$ and $\mathrm{Fe}_{2} \mathrm{O}_{3}$ content of the fly ash limits the utilization, and it is found that catalytic enamel frits show the most 
similar composition with the fly ash. Bulk density of the fly ash is evaluated according to ASTM D7263 - 09(2018)e2 and it was found $0,83 \mathrm{~g} / \mathrm{cm}^{3}$.

The ground coat for the study prepared with frit composition as shown in Table 2. The catalytic enamel frits with the desired composition is derived from Gizem Frit (Sakarya, Turkey). The oxide composition of the catalytic enamel frit is shown in Table 3. The fly ash and frit batch mixed together in 1, 5 and $10 \mathrm{wt}$. \%. The Seger formulations are shown in Table 4.

Table 2. Ground coat frit composition

\begin{tabular}{|l|l|}
\hline Oxides & Percentage (\%) \\
\hline $\mathrm{SiO}_{2}$ & 55 \\
\hline $\mathrm{B}_{2} \mathrm{O}_{3}$ & 10 \\
\hline $\mathrm{Na}_{2} \mathrm{O}+\mathrm{K}_{2} \mathrm{O}+\mathrm{Li} 2 \mathrm{O}$ & 12 \\
\hline $\mathrm{CaO}+\mathrm{MgO}+\mathrm{BaO}+\mathrm{SrO}+\mathrm{ZnO}$ & 10,25 \\
\hline $\mathrm{NiO}+\mathrm{CoO}+\mathrm{CuO}+\mathrm{MnO}$ & 2,65 \\
\hline $\mathrm{Fe}_{2} \mathrm{O}_{3}+\mathrm{Cr}_{2} \mathrm{O}_{3}+\mathrm{Sb}_{2} \mathrm{O}_{3}+\mathrm{P}_{2} \mathrm{O}_{5}+\mathrm{Al}_{2} \mathrm{O}_{3}$ & 5,25 \\
\hline $\mathrm{TiO}_{2}+\mathrm{ZrO}_{2}$ & 4,95 \\
\hline
\end{tabular}

After milling the frit, the enamel powder was sieved down to $170 \pm 10 \mu \mathrm{m}$ and deposited on low-carbon steel panels using two coat - two fire method with Electrostatic Dry Powder Application.

The enamel coating was placed in the preheated furnace at $830^{\circ} \mathrm{C}$ without any heating rate and remained in the heating chamber (Protherm PLF 110/30) for 6 minutes. Coating thickness and surface roughness are important parameters in catalytic enamels. As the surface porosity increases, total surface area increases thus enamel layer gives better catalytic properties. As the thickness of the enamel coating increases the oil intake and fatigue risk increase, and vice versa.

The prepared samples were characterized by means of surface and aesthetic properties with gloss and roughness measurement (Goodwin \& Whitelock, 1985). The color values of the studied samples are obtained via Konica Minolta CM-700d Spectrophotometer. For this study the surface roughness is very important since the catalytic enamel surfaces require porous structure. The surface roughness of the studied specimens was measured using a PosiTector SPG device. The reported values are the average out of 5 measurements.

The gloss was measured using a AMTAST Digital LCD Gloss Meter at an angle of $60^{\circ}$ and the reported values are the average out of 5 measurements.

The self-cleaning properties are evaluated with ISO 8231 (Vitreous and porcelain enamels - Method of test self-cleaning Properties) Test Standard. The standard defines its purpose as enamel coating's ability of absorption of oils that occur during cooking and burning those oils directly without further temperature increase. The pipette is filled with the soy oil at a temperature of $23 \pm 2{ }^{\circ} \mathrm{C}$ to the marking line and the outside is cleaned with a filter paper. The soy oil drop, whose mass is about $20-25 \mathrm{mg}$, is dripped from each of the 5 holes of the template at a height of $20 \mathrm{~mm}$ on the test sample. Five drops of soy oil are also dripped onto the reference sample. (ISO, 2003)

In order to ensure that both samples are exposed to the same thermal and atmospheric conditions, the test sample and the reference sample are placed together on the grid in the oven together with each other. Samples are exposed to $250 \pm 10{ }^{\circ} \mathrm{C}$ for 30 minutes.

After the samples are removed from the oven, they are allowed to cool to air in an ambient temperature of $20-25^{\circ} \mathrm{C}$. The experiment is repeated using the test sample and the reference sample until the surface gloss is observed by naked eye. The number of cycles for which the gloss is observed for the reference sample and test sample is recorded separately.

The dependence of self-cleaning ability can be calculated with respect to time and temperature with different formulas.

Dependence of self-cleaning ability on temperature can be calculated as:

$\mathrm{SC}=\left(0,140 \cdot 10^{-6}\right) \cdot \mathrm{e}^{0,029 \cdot \mathrm{T}}+12,48 \cdot 10^{-3}($ Eq. 1$)$

where $\mathrm{T}$ is represented for temperature and SC means self-cleaning ability. Dependence of self-cleaning ability on exposure time can be calculated as:

$\mathrm{SC}=4,43 \cdot 10^{-3} \cdot \mathrm{t}+6 \cdot 10^{-3}$

(Eq. 2)

where $\mathrm{t}$ is represented for time and SC means self-cleaning ability. (Bragina, et al, 2015) 
Avrupa Bilim ve Teknoloji Dergisi

Table 3 The catalytic enamel frit composition

\begin{tabular}{|l|c|}
\hline Formula & Composition (\%) \\
\hline $\mathrm{SiO}_{2}$ & $28-31$ \\
\hline $\mathrm{Al}_{2} \mathrm{O}_{3}$ & $15-17.5$ \\
\hline $\mathrm{MnO}$ & $8.5-11$ \\
\hline $\mathrm{P}_{2} \mathrm{O}_{5}$ & $5.5-7$ \\
\hline $\mathrm{Na}_{2} \mathrm{O}$ & $5.5-7$ \\
\hline $\mathrm{CaO}+\mathrm{CuO}$ & $8.5-10.5$ \\
\hline $\mathrm{Fe}_{2} \mathrm{O}_{3}$ & $5-6$ \\
\hline $\mathrm{TiO}_{2}$ & $3.8-4.5$ \\
\hline $\mathrm{BaO}$ & $2.2-2.6$ \\
\hline $\mathrm{K}_{2} \mathrm{O}$ & $2.4-2.8$ \\
\hline Other oxides & $5.8-10.2$ \\
\hline
\end{tabular}

Table 4 Seger formulations of the studied samples.

\begin{tabular}{|c|c|c|c|}
\hline \multirow{2}{*}{ Oxides } & \multicolumn{3}{|c|}{ Seger formulations } \\
\cline { 2 - 4 } & $\mathbf{1}$ wt.\% addition & $\mathbf{5}$ wt.\% addition & 10 wt.\% addition \\
\hline $\mathrm{SiO}_{2}$ & 1,497 & 2,800 & 2,100 \\
\hline $\mathrm{Al}_{2} \mathrm{O}_{3}$ & 0,599 & 0,660 & 0,660 \\
\hline $\mathrm{B}_{2} \mathrm{O}_{3}$ & 0,084 & 0,084 & 0,084 \\
\hline $\mathrm{Fe}_{2} \mathrm{O}_{3}$ & 0,200 & 0,200 & 0,200 \\
\hline $\mathrm{MnO}$ & 0,442 & 0,442 & 0,442 \\
\hline $\mathrm{CaO}$ & 0,349 & 0,300 & 0,300 \\
\hline $\mathrm{CuO}$ & 0,120 & 0,120 & 0,120 \\
\hline $\mathrm{BaO}$ & 0,025 & 0,025 & 0,025 \\
\hline $\mathrm{CoO}$ & 0,045 & 0,045 & 0,045 \\
\hline $\mathrm{MgO}$ & 0,100 & 0,150 & 0,150 \\
\hline $\mathrm{TiO}_{2}$ & 0,133 & 0,133 & 0,133 \\
\hline $\mathrm{K}_{2} \mathrm{O}$ & 0,150 & 0,150 & 0,150 \\
\hline $\mathrm{Li}_{2} \mathrm{O}$ & 0,200 & 0,200 & 0,200 \\
\hline $\mathrm{Na}_{2} \mathrm{O}$ & 0,175 & 0,150 & 0,150 \\
\hline $\mathrm{ZrO}_{2}$ & 0,001 & 0,0005 & 0,001 \\
\hline $\mathrm{Cr}_{2} \mathrm{O}_{3}$ & 0,020 & 0,020 & 0,020 \\
\hline $\mathrm{P}_{2} \mathrm{O}_{5}$ & 0,070 & 0,090 & 0,090 \\
\hline
\end{tabular}

\section{Results and Discussion}

The surface roughness property is an important property for catalytic enamels since rougher surfaces have greater specific surface area values. As the surface area of the enamel coating increases, the catalytic activity of the catalyst oxides and the catalytic reaction formation increase. 
Table 5 Roughness values of the studied samples.

\begin{tabular}{|l|l|}
\hline Sample & Surface Roughness $(\mu \mathrm{m})$ \\
\hline Standard & 96 \\
\hline 1 wt. $\%$ & 110 \\
\hline 5 wt. $\%$ & 123 \\
\hline 10 wt. $\%$ & 128 \\
\hline
\end{tabular}

The surface roughness values of the studied samples are shown in Table 5. There is an increase with the standard coating's roughness values and fly ash added samples. Fly ash addition and surface roughness values showed increasing characteristics.

Another important property is the gloss values. Vitreous enamels need to show aesthetic properties, although the rough surface structure decreases the gloss values. Table 6 shows the gloss values of the studied samples.

All the samples present same gloss values, only the $10 \mathrm{wt}$ \% fly ash added sample showed small difference. As a result, it can be seen that fly ash did not distort the surface properties of the catalytic enamel layer and shows a convenience with the base catalytic enamel.

\begin{tabular}{|l|c|}
\hline Sample & Gloss values (at $60^{\circ}$ ) \\
\hline Standard & 0.30 \\
\hline 1 wt. $\%$ & 0.32 \\
\hline 5 wt. \% & 0.33 \\
\hline 10 wt. \% & 0.41 \\
\hline \multicolumn{2}{|r|}{ Table 6 Gloss values of the studied samples at $60^{\circ}$} \\
\hline
\end{tabular}

The color values of the studied samples are shown in Table 7. It is observed that fly ash addition into the catalytic enamel coating decrease the $\mathrm{L}$ values which is the determiner for the white color. The a value, which indicates red color with increase and green color with decrease, increased with the $\% 1$ wt. $\%$ addition however decreased with the 5 wt. $\%$ addition and increased with the 10 wt. $\%$ addition. The $b$ value, indicates yellow color with increase and blue color with decrease, decreased with all additions. Since the color values are effected by too many parameters such as coating thickness and different affecting oxide content, and non-continuous change of the values, no strict comment can be done.

Table 7 Color values (D65 SCE) of the studied samples.

\begin{tabular}{|c|c|c|c|}
\hline Sample & L & A & B \\
\hline Standard & 28.81 & 0.53 & 2.66 \\
\hline 1 wt. \% addition & 23.63 & 0.96 & 2.45 \\
\hline 5 wt. \% addition & 25.83 & 0.43 & 2.16 \\
\hline 10 wt. \% addition & 26.64 & 0.67 & 2.19 \\
\hline
\end{tabular}

The surface topography results are shown in Fig. 3. Standard and K5 samples show very similar results while K1 shows dense structure with peaks and K10 shows dense structure with pits.

The SEM images of the studied samples are shown in Fig. 4. Standard specimen shows typical catalytic enamel coating SEM image owing to its catalyst oxide content like manganese oxide. The $\mathrm{K} 1$ specimen shows distorted structure. The reason of this behavior is probably the addition of fly ash particles with high $\mathrm{Al}_{2} \mathrm{O}_{3}$ and $\mathrm{FeO}$ content distorts the catalytic enamel structure since the addition level is not enough. Also, the K5 and K10 specimens show the same SEM image with the standard catalytic enamel coating.

Hence, as expected, the addition of fly ash into the enamel matrix does not distort the catalytic enamel structure. Also, when K5 and K10 samples are compared, it can be seen that K5 sample shows more similarity with the standard catalytic enamel sample. K10 sample shows big particles in the enamel matrix with dense structure. From the above information about surface quality properties and SEM/EDS analysis, it can be stated that the amount of added fly ash particles has a threshold value which limits the addition and distorts the surface properties. However, the catalytic activity not only depends on surface roughness, also depends on the self-cleaning ability results. 

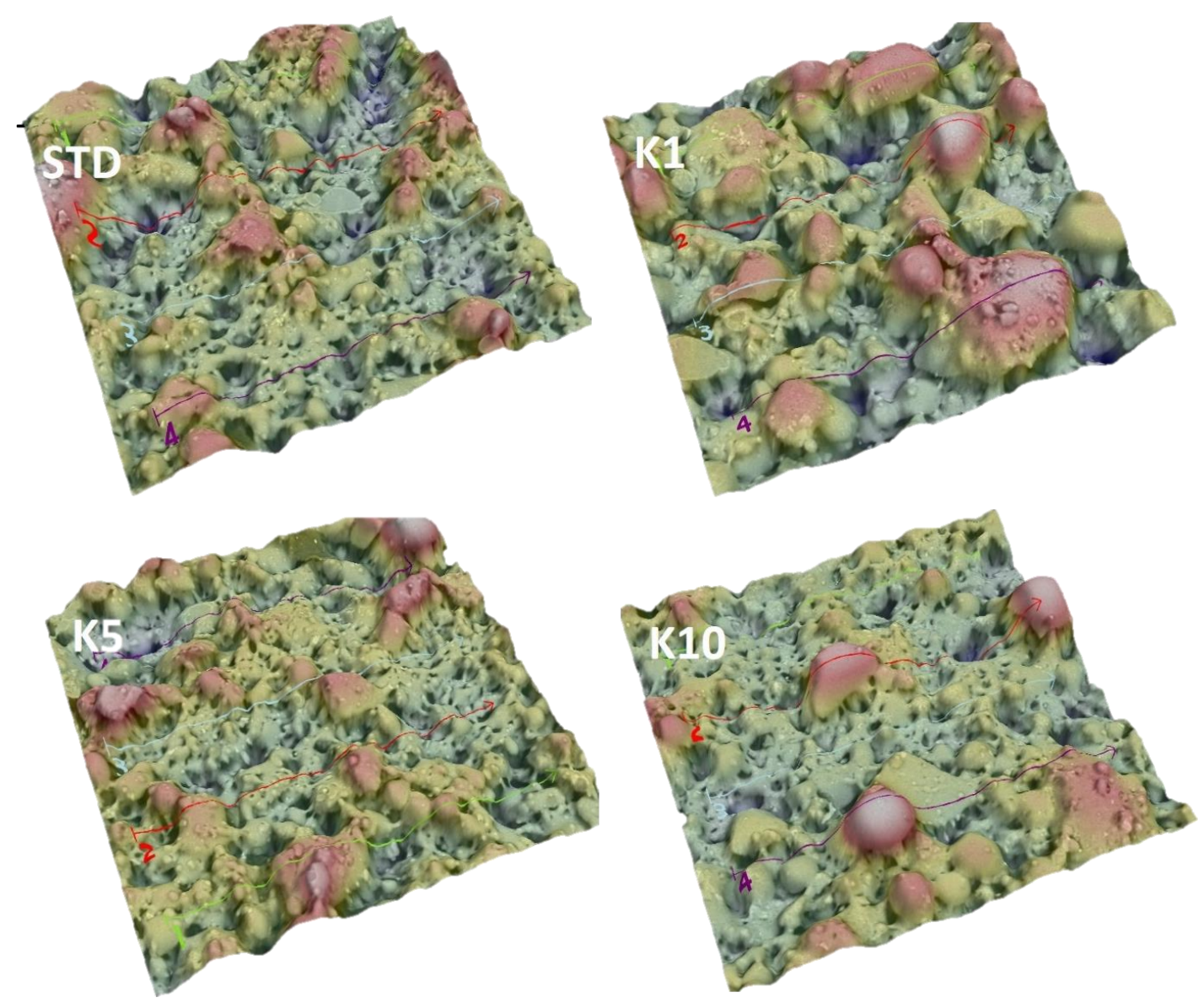

Figure 3: Surface topography results of the studied samples. 
European Journal of Science and Technology
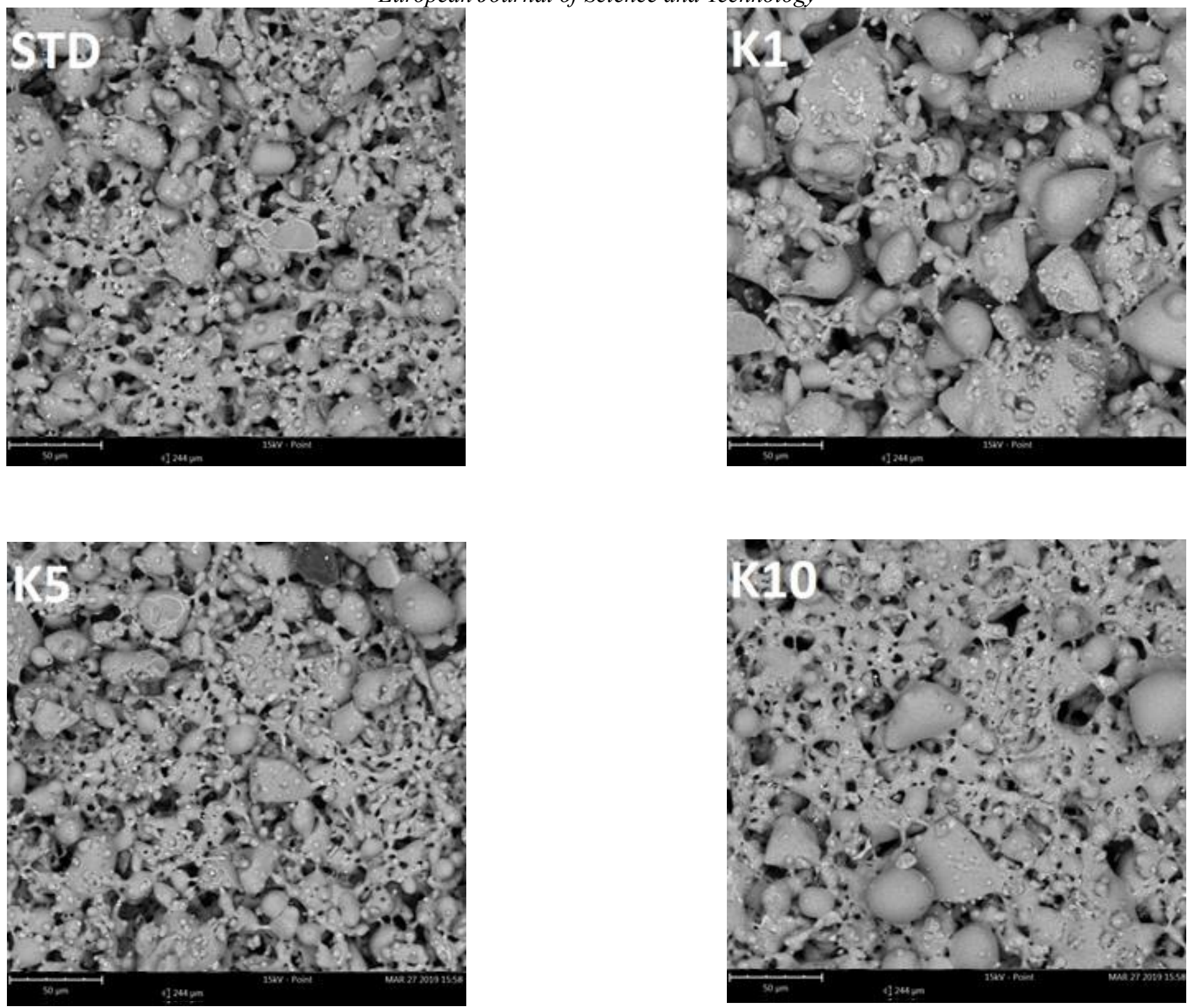

Figure 4: SEM images of the studied samples: STD: standard catalytic enamel, K1: 1 wt. \% fly ash addtion, K5: 5 wt. \% fly ash addition and K10: 10 wt. \% fly ash addition

The EDS analysis of the studied samples are shown in Figure 5. All the samples show approximately same results in EDS analysis in the means of quantification. However, it can be seen that as the fly ash addition does not distort catalyst oxide content. K5 sample shows the best similarity with the standard sample without fly ash addition. In the sample marked as K1, the fly ash addition is not enough for the catalytic enamel coating since the SEM image shows a distorted and different micro structure than the standard coating. K10 sample shows that the addition of fly ash increases crystal content, since the fly ash particles mostly consist of $\mathrm{SiO}_{2}$ molecules and increasing content of $\mathrm{B}_{2} \mathrm{O}_{3}$ and $\mathrm{Li}_{2} \mathrm{O}$ in the developed formulas, also increases the particle sizes of the catalyst oxides. Still, the morphology and the surface properties are not enough parameters for the self-cleaning ability. 

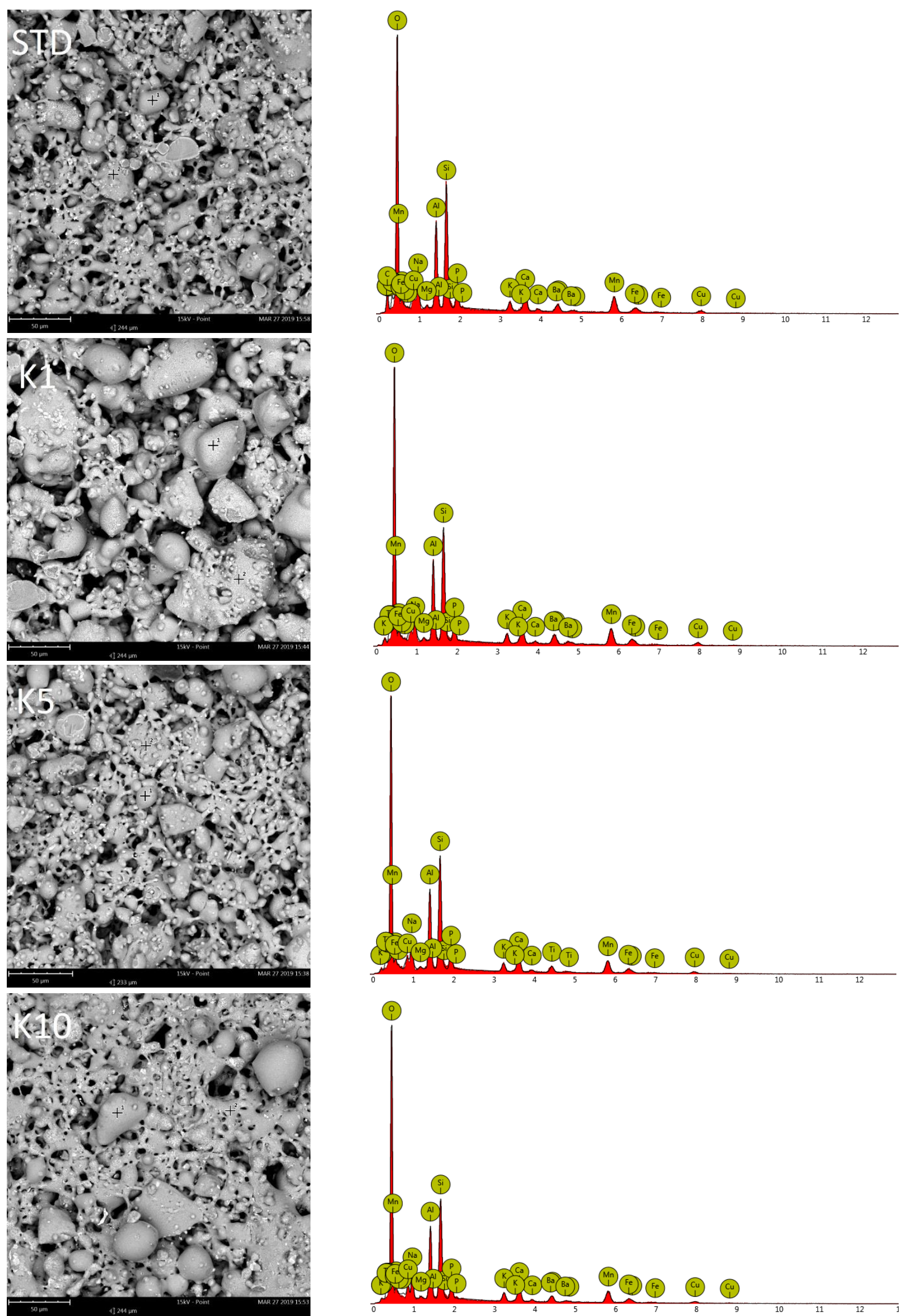

Figure 5 EDS analysis of the studied samples; STD: standard catalytic enamel, K1: 1 wt. \% fly ash addtion, K5: 5 wt. \% fly ash addition and K10: $10 \mathrm{wt}$.\% fly ash addition 
The self-cleanability test was made with according to ISO 8291 Test Standard. The test results were same for the all samples which is 8 cycles. It means that a gloss which is caused by the oil drops is observed in the samples at the $8^{\text {th }}$ cycle.

The self-cleaning ability of the coating tested by measuring weight loss of soy oil and the dependence of the time and exposure temperature have a linear and exponential characteristic respectively. Fig. 6 and Fig. 7 show dependence of self-cleaning ability on temperature and exposure time.

Fig. 6 shows that addition of fly ash into the catalytic enamel shows accordance with the catalytic enamel working temperatures which is $200-250{ }^{\circ} \mathrm{C}$ in the domestic uses. In Fig. 7, catalytic enamels in cooking devices like ovens, needs time for cooking and also activating the catalytic activity so that catalytic activity must increase with increasing exposure time. Fly ash added catalytic enamels also show suitability in this regard.

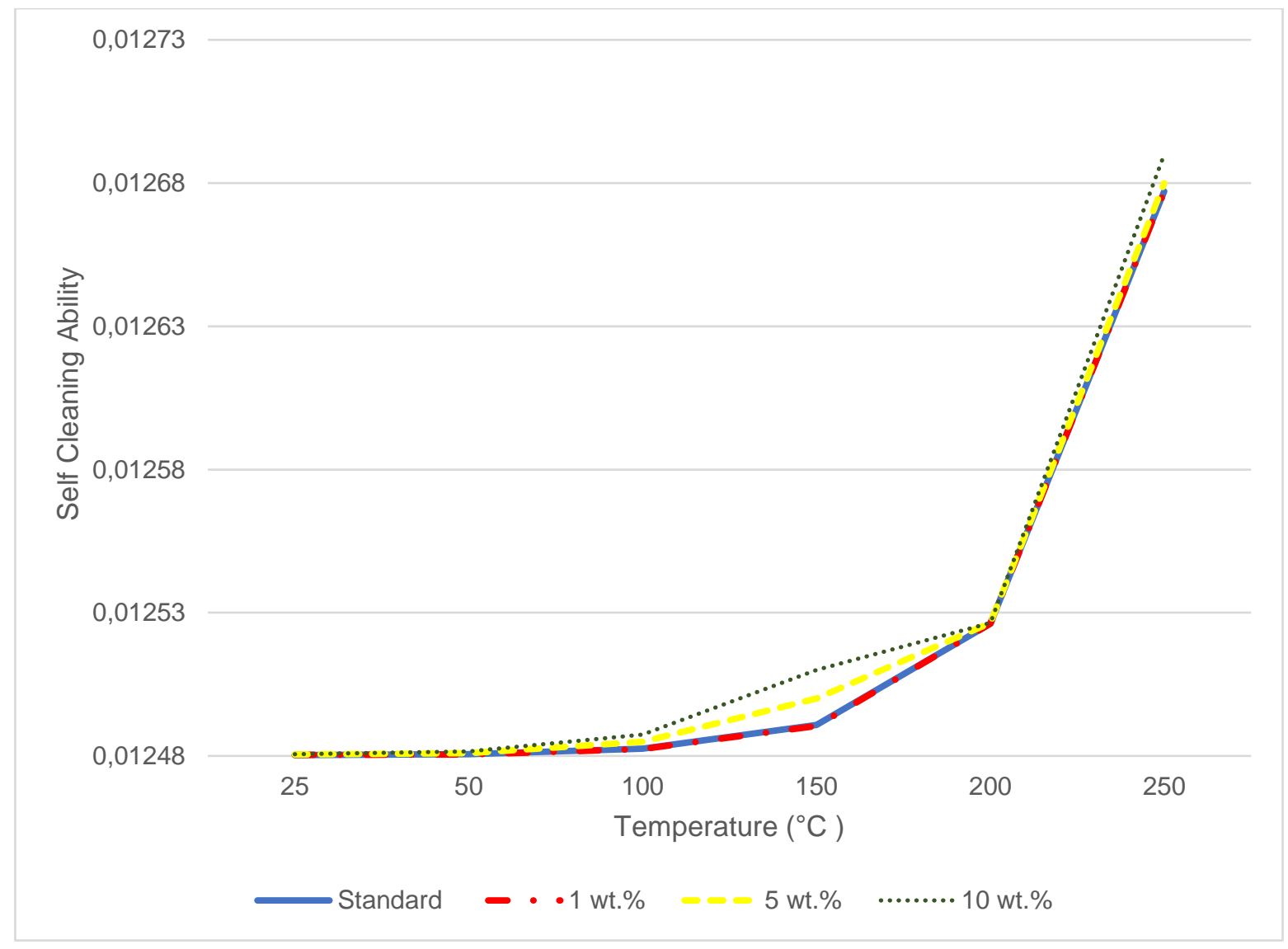

Figure 6. Dependence of self cleaning ability on temperature 


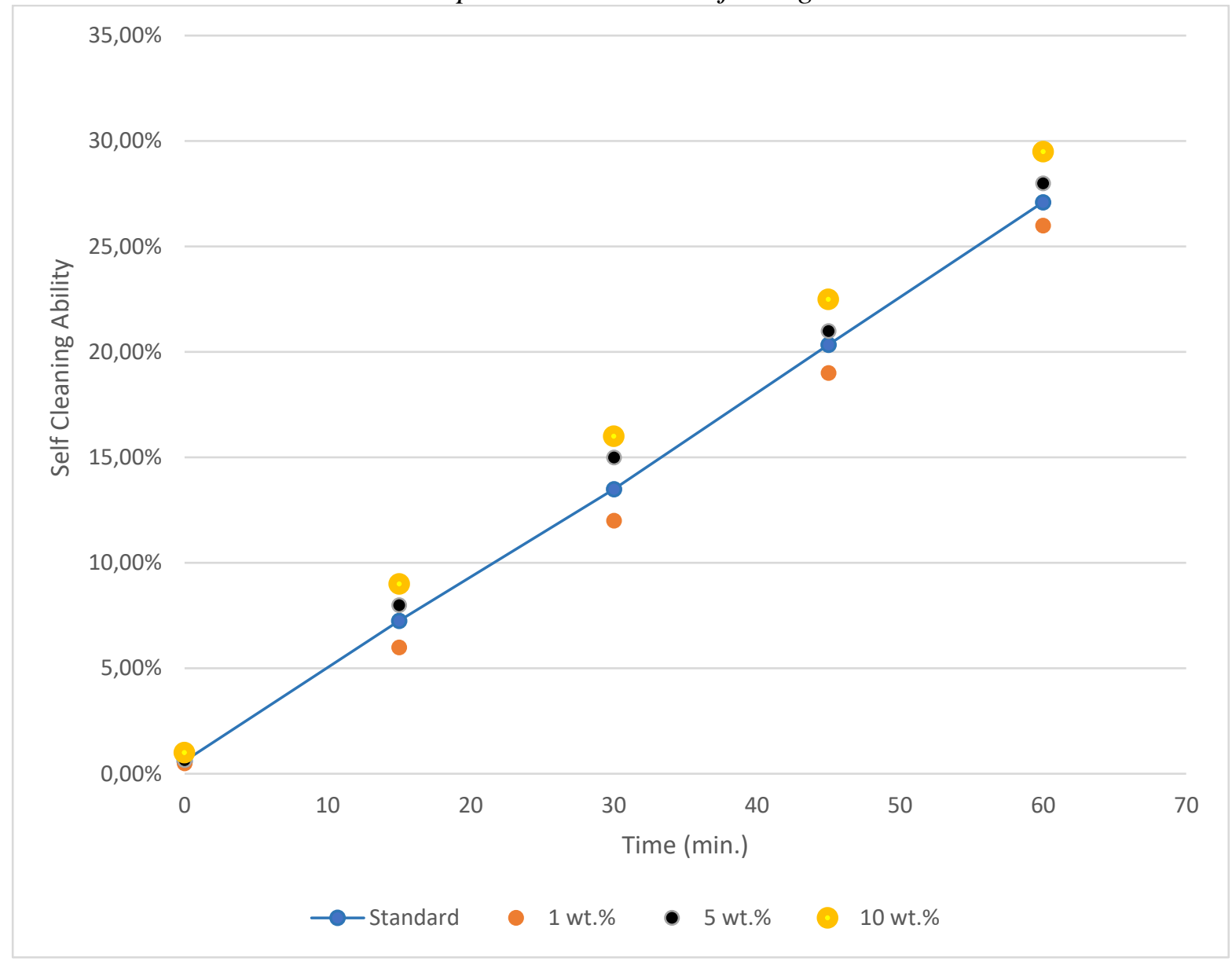

Figure 7. Dependence of self cleaning ability on exposure time

\section{Conclusion}

Fly ash, a product from the power plants still remain as one of the most promising by product and raw material for ceramics and glassceramic industry. The amount of untreated fly ash addition particles into the enamel composition is studied in the manners of enamel production. Fly ash particles obtained from the AKSA Acyclic Chem Co. was added to the enamel matrix with the varying amounts in to the catalytic enamel frit. The comparison was made between standard catalytic enamel and $1 \mathrm{wt} . \%, 5 \mathrm{wt} . \%$ and $10 \mathrm{wt} . \%$ fly ash added compositions. Depending on the premier results developed decided compositions were applied and analysed under industrial production conditions. Microstructural properties were observed together with gloss and surface roughness characteristics. For a convenient industrial application and the catalytics activity ISO 8291 test was applied to all samples. As a result, the use of fly ash particles with the catalytic enamel does not have structural drawbacks and showed suitability with the catalytic enamel frits.

\section{Acknowledgements}

I would like thank Res. Eng. Mr. Nurullah Çöpoğlu and Gizemfrit Glaze and Ceram. Co Research and Development Center for the Industrial help they provide for the research

\section{References}

ASTM. (2005). Specification for Coal Fly Ash and Raw or Calcined Natural Pozzolan for Use in Concrete. Philadelphia: American Society for Testing and Materials .

Barberio, G., Buttol, P., Masoni, P., Scalbi, S., Andreola, F., Barbieri, L., \& Lancellotti, I. (2010). Use of Incinerator Bottom Ash for Frit Production. Journal of Industrial Ecology, 14(2), 200 - 2016. https://doi.org/10.1111/j.1530-9290.2010.00224.x

Bragina, L., Shalygina, O., Kuryakin, N., Guzenko, N., Hudiakov, V., \& Annenkov, V. (2015). Vitreous Enamels for Easy-to-Clean and Catalytic Coatings. International Enamellers' Congress. Florence.

Cheng, T. W., Ueng, T. H., Chen, Y. S., \& Chiu, J. (2002). Production of glass-ceramic from incinerator fly ash. Ceramics International, 28(7), 779 - 783. https://doi.org/10.1016/S0272-8842(02)00043-3

Clean Coal Technologies in Japan. (2007). Coal Ash Generation Process and Application Fields. Tokyo: Japan Coal Energy Center (JCOAL). Retrieved from http://www.jcoal.or.jp/eng/cctinjapan/2_5C1.pdf 
European Journal of Science and Technology

Erol, M., Küçükbayrak, S., Ersoy-Meriçboyu, A., \& Öveçoğlu, L. (2001). Crystallization behaviour of glasses produced from fly ash. Journal of the European Ceramic Society, 21(16), 2835 - 2841. https://doi.org/10.1016/S0955-2219(01)00221-7

Erol, M., Küçükbayrak, S., Ersoy-Meriçboyu, A., \& Öveçoğlu, L. (2004). Crystallization kinetics of fly ash based glasses. Key Engineering Materials, 264 - 268, 1895-1898. https://doi.org/10.4028/www.scientific.net/KEM.264-268.1895

Goodwin, J., \& Whitelock, K. P. (1985). The importance of colour and its stability in vitreous enamels. Materials \& Design, 6(4), 172176. https://doi.org/10.1016/0261-3069(85)90039-1

Höland, W., \& Beall, G. (2002). Glass-Ceramic Technology. Ohio: The American Ceramic Society.

Höland, W., \& H.Beall, G. (2013). Glass-Ceramics. Handbook of Advanced Ceramics (pp. 371 - 381). Massachusetts: Academic Press.

ISO. (2003). ISO 8291 - Vitreous and porcelain enamels - Method of test self-cleaning properties. London: International Organization for Standardization.

Karamanova , E., \& Karamanov, A. (2009). Glass-ceramic frits from fly ash in terracotta production. Waste Management \& Research, 27(1), 87 - 92. https://doi.org/10.1177/0734242X08088694

Kim, H. S., Kim, J. M., Oshikawa, T., \& Ikeda, K. (2003). Production and Properties of Glass-Ceramic from Incinerator Fly Ash. Materials Science Forum, 439, 180 - 185. https://doi.org/10.1016/S0272-8842\%2802\%2900043-3

Ramzi Hannan, N., Shahidan, S., Maarof, M., \& Noorwirdawati, A. (2017). Physical and Chemical Properties of Coal Bottom Ash (CBA) from Tanjung Bin Power Plant. International Engineering Research and Innovation Symposium (IRIS) . Melaka. https://doi.org/10.1088/1757-899X/160/1/012056

Sahu, B. K., \& Jayaram, S. (2000). Environmental Impacts of Fly Ash. Bostnawa Journal of Technology, pp. 9-13.

Sear, L. K. (2001). Properties and Use of Coal Fly Ash - A Valuable Industrial By-Product. London : Thomas Thelford Publishing.

Shalygina, O., Bragina, L., \& Kuryakin, M. (2012). Powder Electrostatic Technology of House Hold Appliances Enamelling. Chemistry and Chemical Technology, 6(4), 435 - 441. https://doi.org/10.23939/chcht06.04.435

Snellings, R., Mertens, G., \& Elsen, J. (2012). Supplementary Cementitious Materials. Reviews in Mineralogy and Geochemistry, 74(1), 211-278. https://doi.org/10.1016/j.cemconres.2010.12.001

Sun, S., Li, H., \& Xu, Z. J. (2018). Impact of Surface Area in Evaluation of Catalyst Activity. Joule, 1024-1027.

Türker, P., Erdoğan, B., Katnaş, F., \& Yeğinobalı, A. (2009). Türkiye'deki Uçucu Küllerin Sinıflandırılması ve Özellikleri. Ankara: Turkish Cement Manufacturers Association. 